18.5 p. 100 of the DM during the growing period (up to $58 \mathrm{~kg}$ ) and from 14.1 to $15.8 \mathrm{p}$. 100 during the finishing period (up to $102 \mathrm{~kg}$ ). The lysine levels varied similarly between 0.95 and 1.06 p. 100 , then between 0.75 and 0.83 p. 100 . No significant interaction was observed between the effects of protein and those of lysine on performance or on carcass yield. During the growing period, the increased lysine supply from 2.77 to $3.16 \mathrm{~g} /$ $1000 \mathrm{Kcal} \mathrm{DE}$ led to a highly significant improvement of the daily mean gain $(683$ to $712 \mathrm{~g} / \mathrm{d})$ and of the feed conversion ratio $(2.13$ to 2.05 for DM and 7.19 to $6.86 \mathrm{Mcal}$ for DE). Opposite to that, the protein level did not affect the performance. During the finishing period, the minimum protein and lysine levels were sufficient to obtain the maximum growth rate of $760 \mathrm{~g} / \mathrm{d}$ fixed by the feed restriction plan, i.e. : $1850 \mathrm{~g}$ feed supplement and $16 \mathrm{l}$ whey. During the growing and the finishing period no difference was observed between males and females. However, this difference was highly significant as regards the carcass characteristics : females exhibited a lean and bone percentage of 53.6 p. 100 versus 51.5 p. 100 in males, and a fat percentage of 38 p. 100 versus 40.4 p. 100 . Lysine significantly increased the ham weight $(+500 \mathrm{~g})$, while the highest protein levels increased the lean percentage $(52.1$ to $53.0 \mathrm{p}$. 100). Increase in the protein and lysine levels had a beneficial effect on meat quality. The highest lysine levels led to a water loss reduction.

\title{
Effect of skim milk powder in weaning diets for piglets Role of the dietary protein level
}

\author{
F. WILLEQUET*, B. SEVE**, G. BERTRAND**, P. QUEMERE * \\ * S.E.R.E.P., route de Crèvecaur, 60026 Beauvais \\ *: I.N.R.A., Station de Recherches sur I'Elevage des Porcs, \\ Saint-Gilles, 35590 L'Hermitage.
}

France

Six trials were made in 580 piglets weaned at three weeks to test the effect of the incorporation of skim milk powder in two diets containing 18 and $22 \mathrm{p}$. 100 crude protein, respectively. The diets were offered ad libitum in the form of pellets during the first fortnight following weaning (1st age). Whatever the diet, the feed intake and live weight gain tended to increase with the initial weight at weaning. However, this did not improve systematically the feed efficiency. There was no significant relationship between the effects of milk powder and those of the crude protein content. The incorporation of skim milk powder did not modify the feed intake, but improved significantly the live weight gains as well during the first age as during the whole experimental period $(+5$ p. 100). The feed efficiency was also improved by $5 \mathrm{p} .100$. The increase in the crude protein content of the diet had a favourable effect on the daily weight gain and feed efficiency which was as marked as that of the milk powder, but it did not affect the feed intake.

\section{Long-term effects of reducing the protein level in a simplified weaning diet for piglets}

\author{
B. SEVE \\ I.N.R.A., Station de Recherches sur l'Elevage des Porcs, \\ Saint-Gilles, 35590 L'Hermitage \\ France
}

A total of 180 piglets from 30 litters weaned between the age of 19 and 25 days were reared individually from weaning to slaughter. Six 1 st age diets were compared 